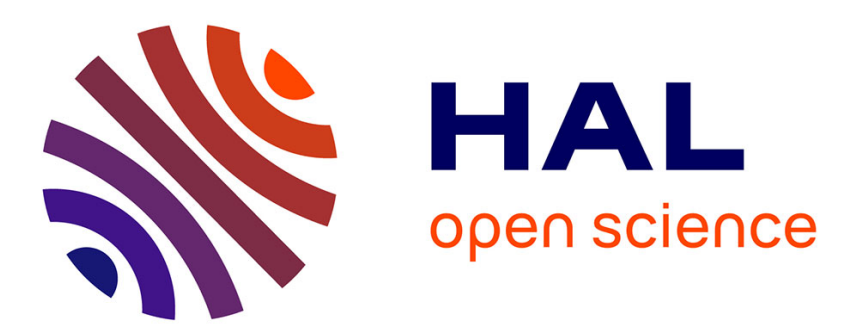

\title{
Long-term monitoring of activities of badgers (Meles meles L.) in a broadleaved forest in France
}

François F. Lebourgeois

\section{To cite this version:}

François F. Lebourgeois. Long-term monitoring of activities of badgers (Meles meles L.) in a broadleaved forest in France. European Journal of Wildlife Research, 2021, 67 (1), 10.1007/s10344020-01447-1 . hal-03102314

HAL Id: hal-03102314

https://hal-agroparistech.archives-ouvertes.fr/hal-03102314

Submitted on 10 Jun 2021

HAL is a multi-disciplinary open access archive for the deposit and dissemination of scientific research documents, whether they are published or not. The documents may come from teaching and research institutions in France or abroad, or from public or private research centers.
L'archive ouverte pluridisciplinaire HAL, est destinée au dépôt et à la diffusion de documents scientifiques de niveau recherche, publiés ou non, émanant des établissements d'enseignement et de recherche français ou étrangers, des laboratoires publics ou privés. 
Lebourgeois F., Long-term monitoring of activities of badgers (Meles meles L.) in a broadleaved forest in France. European Journal of Wildlife Research, 2021, 67:8, doi.org/10.1007/s10344-020-01447-1

THIS IS MY PERSONAL LAYOUT OF THE ARTICLE

\title{
Long-term monitoring of activities of badgers (Meles meles L.) in a broadleaved forest in France
}

\author{
Lebourgeois François \\ https://orcid.org/0000-0002-2040-6150 \\ francois.lebourgeois@agroparistech.fr \\ Université de Lorraine, AgroParisTech, INRAE, Silva, 54000, Nancy, France
}

Keywords Meles meles L., daily activities, camera-trapping, long-term monitoring, northeastern French broadleaved forest

\begin{abstract}
European badgers' behaviors have been studied over a six years period (2013-2018) using camera traps settled in a main sett $\left(400 \mathrm{~m}^{2} ; 17\right.$ holes) in an oak forest, northeastern France. I analyzed group's size, grooming, digging, bedding collecting, mating, and the emergence and return times. The burrow was inhabited by 2.8 ( \pm 1.2 ) badgers. I observed between 2 to 4 new cubs each year in five out of six years, with a first emergence in mid-April. Grooming was frequent after emergence at dusk and lasted around $10 \mathrm{~min}$ (more frequent grooming in April after the births). Bedding collecting was a major activity in February and March during dry nights (mean duration of around 20 min) for years with births. Digging occurred only in winter 2015 and spring 2016, mainly at dusk (mean: 23 min, 2 to 90 min). Mating occurred mainly in January and February with short $(<10 \mathrm{~min})$ and long $(>60 \mathrm{~min})$ duration of copulation. Emergences occurred mainly between 19 and $21 \mathrm{~h}$ and returns between 5 and $7 \mathrm{~h}$. For spring and summer, badgers emerged between 30 and 60 min before sunset but $2 \mathrm{~h}$ or more after sunset in autumn and winter. Returns occurred before sunrise in the middle of the night ( $1 \mathrm{~h}$ in spring and summer and $2 \mathrm{~h}$ or more in autumn and winter). In autumn and winter, warm days hastened emergences time (i.e., maximum temperature higher than $10^{\circ} \mathrm{C}$ ) and frost nights hastened returns (i.e., minimum temperature below $0^{\circ} \mathrm{C}$ ).
\end{abstract}




\section{INTRODUCTION}

The European badger (Meles meles L.) is a medium-sized carnivore species widely distributed throughout Europe (Frantz et al. 2014). Badger is a communally dwelling mammal forming well-organized family groups that live in a burrow system (Neal 1986; Thornton 1988; Lebourgeois 2020a, b). The cohesion of the group calls upon many social behaviors: vocalizations (Wong et al. 1999), grooming and scent marking (Buesching et al. 2003), digging, and bedding collecting (Roper 1992; Roper et al. 1991). A thorough grooming ensures the elimination of the parasites and helps to share scent among the different group members. The digging ensures maintenance of the burrow and the creation of new tunnels, sleeping, and breeding chambers to welcome new animals. Digging also maintains optimal underground conditions (Roper and Moore 2003) and avoid accumulation of ectoparasites (Butler and Roper 1996). The function of bedding collecting, which is a specific badger trait, may be related to preventing heat loss particularly during winter or to maintaining the cleanliness of the sleeping and breeding chambers (Neal 1986).

I used a non-invasive monitoring method of camera trapping (Balestrieri et al. 2016; Findlay et al. 2017) to follow continuously the daily activities of a family group over six years (from April 2013 to June 2018) including grooming, digging, bedding collecting, mating, and the emergence and return times. Although these behaviors have been known for a long time, their seasonal variability remains poorly documented (Neal 1986), as well as the importance of weather conditions in particular on bedding collecting and daily activity rhythms. Sunrise and sunset times influence the daily activity patterns (Cresswell and Harris 1988; Kowalczyk et al. 2003; Neal 1986) but many other factors such as temperature, rainfall, cloud cover, air humidity or wind speed are also cited as significant determining factors of badger's behaviors (Martin et al. 2017; Noonan et al. 2014). In addition to sunset and sunrise times, it was hypothesized that the badger's behavior would significantly change during warm or cold days or under dry or wet conditions and that these climatic interactions would differ throughout the seasons. To highlight the role of weather conditions on activity patterns and possible interactions between climatic parameters, I used daily meteorological data in my analyses.

\section{MATERIALS AND METHODS}

The monitored main sett (i.e., badger burrow) is located in a typical oaks (Quercus petraea and robur), beech (Fagus sylvatica) and hornbeam (Carpinus betulus) lowland forest of the "Plaine Lorraine » in the northeastern France (area of the forest $\sim 1.5 \mathrm{~km}^{2} ; 48.69 \mathrm{~N}-06.27 \mathrm{E}$; alt. $300 \mathrm{~m}$ ). The sett is located in the center of the forest (that included one other main sett and six outliers) (Thornton 1988) far from human activities and potential disturbance. The nearest edge is around 300 meters away and the furthest is around $1300 \mathrm{~m}$. From 2013 to 2018, the area of the burrow increased from $150 \mathrm{~m}^{2}$ with 8 entrances to $400 \mathrm{~m}^{2}$ with 17 holes. The holes averaged $50 \pm 20 \mathrm{~cm}$ wide and $40 \pm 15 \mathrm{~cm}$ high. These characteristics are typical of the main forested burrows observed in the "Plaine Lorraine" (Lebourgeois 2020a). The site has a mean annual precipitation and temperature of $774 \mathrm{~mm}$ and $10.5^{\circ} \mathrm{C}$, respectively (Météo-France-Nancy; alt. $212 \mathrm{~m} ; 48.41 \mathrm{~N}-06.13 \mathrm{E} ; 1981-2010)$. The coldest month is January (mean temperature of $2^{\circ} \mathrm{C}$ ) and the warmest is July (mean temperature of $19^{\circ} \mathrm{C}$ ). In winter, days (more 
rarely many weeks) can be cold (ranging from -5 to $-10^{\circ} \mathrm{C}$ ) but snow is very rare and melts quickly. Precipitation are regularly distributed over all months (50 to $70 \mathrm{~mm}$ per month).

To follow the different activities, three camera traps (Bushnell Trophy Model 119477 and Cam HD Model 119877) were tied to tree trunks ( 1 to $1.5 \mathrm{~m}$ above the ground). The camera traps covered the entire area of the burrow and the overall holes (active and inactive) ensuring the reliability of the collected data. The cameras were set to record 60-s-long videoclips with a $3-$ s interval between two successive recordings throughout the 24 -h period (day/night) (Findlay et al. 2017). The monitoring lasted 1538 days between the 1 April 2013 and the 23 June 2018 during all seasons (243 weeks and 29648 videos). Because only slender morphological differences exist between badgers (Dixon 2003), an accurate analysis at the individual level was not possible (except for mating insured by the dominant female of the group, easily recognizable by a white mark on the back). Thus, the behaviors presented must be considered at the family group level and not at the individual one. For the nightly variations of the different activities, three periods were defined: after emergence "dusk period" [18 to $24 \mathrm{~h}$ [, during the night "night period" $[0-4 \mathrm{~h}]$ and before the return into the burrow "dawn period" ]4-9h]. The daily local sunrise and sunset times and the duration of the day and night were considered for the latitude $48.69 \mathrm{~N}$. To highlight the effect of climate on the different activities, daily precipitation, temperature, wind speed, air humidity, sunshine duration, global solar radiation, and potential evapotranspiration were gathered from the station of Nancy $(7 \mathrm{~km}$ away from the forest).

\section{RESULTS AND DISCUSSION}

From 2013 to 2018, the burrow was regularly inhabited by $2.8( \pm 1.2)$ badgers (maximum: 9 badgers) and cubs have been observed five years out of six (2 to 4 cubs per year). The first emergence of the cubs was usually observed in mid-April (between the first and 20 April).

Grooming has been observed in $39 \%$ of the cases and occurred mainly at dusk after the emergence of the burrow (Table 1 and Fig. 1). Grooming was more frequent at the end of winter and during spring and less important during summer and autumn (Table 2). Two peaks have been observed in April (after the emergence of the cubs) and in October. Grooming lasted usually less than 10 minutes (maximum duration: $45 \mathrm{~min}$ ).

Bedding collecting took place almost exclusively at dusk and averaged 12 minutes (maximum duration around 150 min) (Tables 1 and 2, Fig. 2). Bedding collecting was typically carried out by a single adult (rarely two in a same time). The bedding dragged into the burrow was made up exclusively of bundles of hornbeam leaves collected in the surrounding area of the burrow (between five to 20-30 meters; maximum around 50 meters). It was more important in February (mean duration 23 min) and March and in October and November (mean duration 18 min). Between mid- and the end of February, badgers collected bedding regularly between three to six days out of seven. This observation confirms the suggestion made by Neal (1986) that the peak in February is closely connected with preparations for the birth of the cubs which occurs during this period (Cresswell et al. 1992; Page et al. 1994). Indeed, for the five years with births, badgers devoted 23 days in average (17 to 34 days) to collect litterfall in February and March. In 2016, with no litter born, bedding 
collecting was observed only eight times. During these two months, suitable conditions for bedding collecting correspond to dry nights. Indeed, 95\% of the nights with bedding collecting had little to no rainfall (no rainfall - $84 \%$ - or rainfall below $1 \mathrm{~mm}-11 \%$ ). Conversely, the nights without bedding collecting were rainy in $63 \%$ of the cases (43\% with rainfall above 1 mm; mean: $5.9 \pm 4.3 \mathrm{~mm}$ ). Dry bedding prevents heat loss into the burrow which increase the survival and the weight of the new-born cubs (Tsunoda et al. 2018). Peak bedding in autumn also coincided with dry nights (90\% of the nights had rainfall lower than $1 \mathrm{~mm}$ ). It plays a major role to prepare the sleeping chambers for the cold season. Indeed, maintaining body temperature is more energetically expensive under cold and wet conditions. Thus, a "high" and stable internal sett temperature allows to minimize the body temperature loss (badgers' body were around 2 to $3{ }^{\circ} \mathrm{C}$ colder in winter than in the rest of the year) and thus to decrease the metabolic saving (Bevanger and Broseth 1998).

The digging of new holes has been observed during the winter 2015-2016 with a peak in September and October 2015 followed by an important activity in April and May 2016 (Tables 1 and 2). In October, badgers frequently dug but with a shorter duration which corresponded to the refreshing of the external zone of the preexisting holes. Badgers dug a total of during 58 hours during the six years of monitoring.

During the six years, we observed a total of 62 mating events, mostly at dawn with a marked peak in January and February highlighting the high sexual activity in winter (Tables 1 and 2). This pattern is associated with the increasing testis weight, sperm production and testosterone levels observed in winter (Ahnlund 1980;
Buesching et al. 2009; Paget and Middleton 1974) and with the post-parturient ovulation occurring after the birth of the cubs (Canivenc and Bonnin 1979; Wandeler and Graf 1982). Forty-seven percent of the mating lasted less than 20 min $(n=15$; mean $=7 \mathrm{~min})$ and $63 \%$ more than $20 \mathrm{~min}(\mathrm{n}=17$; mean $=70 \mathrm{~min})$. The longest mating lasted 150 min with two consecutive periods (90 and $60 \mathrm{~min}$ ).

Badgers showed regular crepuscular and nocturnal activities depending on photoperiod and daily temperatures. For the long days ( $>12$ hours; spring and summer), badgers began their outside activity (19h30 to 21h30) between 30 and 60 min before sunset and $2 \mathrm{~h}$ or more after sunset for the short days (autumn and winter; $18 \mathrm{~h}$ to 20h30) (Fig. 3). During the short days, a daily maximum temperature higher than $10^{\circ} \mathrm{C}$ hastened burrow emergence by around one hour compared to the emergence time observed during fresh days (0 to $5^{\circ} \mathrm{C}$ ) (Fig. 3). Badgers were always back to the burrow one to two hours before sunrise (return times $4 \mathrm{~h} 30$ to $5 \mathrm{~h} 30$ during the long days of spring and summer, return times between $5 \mathrm{~h} 30$ and $7 \mathrm{~h} 30$ during the shorter days of autumn and winter) (Fig. 4). As observed for the emergence, daily temperature also influenced the return. In winter, return time was hastened by around one hour during particularly frosty nights (minimum temperature between -5 and $10^{\circ} \mathrm{C}$ ) compared to the return time observed for nights without frost $\left(>0^{\circ} \mathrm{C}\right)$ (Fig. 4). This clear contrast between warm and frost nights has been already reported in the literature (Do Linh San et al. 2010; Kowalczyk et al. 2003; Lindsay and Macdonald 1985). Badgers show a strong external thermal regulation with a better conservation of energy and fat reserves under warm conditions in winter (Bevanger and Broseth 1998; McClune et al. 2015; Tanaka 2006). This metabolism could 
explain why warm nights hastened the emergence time and frost nights quickened the return. Another explanation could be linked to the diet of badgers that fed mainly on earthworms in temperate forests ( $\mathrm{Li}$ et al. 2013). Most earthworm species are active within a temperature range of 0 to $20^{\circ} \mathrm{C}$ (Curry 2004; Nordström 1975) and soil temperature and humidity influence the presence of available earthworms on the surface in foraging areas. "Worm nights" have been defined as warm nights $\left(>0^{\circ} \mathrm{C}\right)$ with the upper part of the soil slightly humid (Kruuk and Parish 1981). Thus, a linearly increase of earthworm's capture between 0 and 150 per night has been observed for an increase of external temperature from 0 to $8^{\circ} \mathrm{C}$ (Henry 1984; Lambert 1990). Under these favourable conditions that improve earthworm availability, badgers emerge usually earlier and devote less time to foraging (higher energetic efficiency) (Henry 1984; Kowalczyk et al. 2003). Obviously, the foraging behaviour of animals depends not only of external conditions but also on the resource availability (Shepherdson et al. 1990). The forest under study is one of the most favourable contexts for badgers with high earthworm availability (i.e., broadleaved forests with rich and loose soils) (Lebourgeois 2020a).

As many other researchers, I am aware of the importance of badgers' life underground but due to difficult study conditions very few studies have been done on their subterranean behaviour (Markham et al. 2012; Noonan et al. 2015). Here, I present original results on some specific aboveground badger's traits and confirm the high interest of camera trapping to study wild animals. It appears also very important to perform a long term monitoring to highlight the seasonal variability of the different behaviors and to evaluate their duration. The study has been performed on a single burrow but the group size and the characteristics of the burrow are very representative of the main burrows observed in temperate broadleaved forests in the area (Lebourgeois 2020a, b). Complementary studies on a larger territory (systematic cartography of the burrows in the main forest areas of the "Plaine Lorraine") and sample (seasonal monitoring of around 30 burrows) are in progress and should reinforce the results of this study.

\section{REFERENCES}

Ahnlund H (1980) Sexual maturity and breeding-season of the badger, Meles meles in Sweden. Journal of Zoology 190: $77-95$

Balestrieri A, Cardarelli E, Pandini M, Remonti L, Saino N, Prigioni C (2016) Spatial organisation of European badger (Meles meles) in northern Italy as assessed by camera-trapping. European Journal of Wildlife Research 62(2): 219-226

Bevanger K, Broseth H (1998) Body temperature changes in wild-living badgers Meles meles through the winter. Wildlife Biology 4(2): 97-101

Buesching CD, Heistermann M, Macdonald DW (2009) Seasonal and inter-individual variation in testosterone levels in badgers Meles meles: evidence for the existence of two endocrinological phenotypes. Journal of Comparative Physiology a-Neuroethology Sensory Neural and Behavioral Physiology 195(9): 865-871

Buesching CD, Stopka P, MacDonald DW (2003) The social function of allo-marking in the European badger (Meles meles). Behaviour 140: 965-980 
Butler JM, Roper TJ (1996) Ectoparasites and sett use in European badgers. Animal Behaviour 52: 621-629

Canivenc R, Bonnin M (1979) Delayed implantation is under environmental control in the badger (Meles meles L.). Nature 278: 849-850

Cresswell W, Harris S (1988) The effects of weather conditions on the movements and activity of badgers (Meles meles) in a suburban environment. Journal of Zoology 216: $187-194$

Cresswell WJ, Harris S, Cheeseman CL, Mallinson PJ (1992) To breed or not to breed - an analysis of the social and density-dependent constraints on the fecundity of female badgers (Meles meles). Philosophical Transactions of the Royal Society of London Series B-Biological Sciences 338(1286): 393-407

Curry JP (2004) Factors affecting the abundance of earthworms in soils. In: Edwards CA (ed) Ecology, earthworm. Boca Raton, pp 91-113

Dixon DR (2003) A non-invasive technique for identifying individual badgers Meles meles. Mammal Review 33(1): 92-94

Do Linh San E, Ferrari N, Weber JM (2010) Circadian activity patterns and nocturnal resting sites of Eurasian badgers (Meles meles L.) in a rural area of western Switzerland. Revue Suisse De Zoologie 117(1): 111-119

Findlay MA, Briers RA, Diamond N, White PJC (2017) Developing an empirical approach to optimal camera-trap deployment at mammal resting sites: evidence from a longitudinal study of an otter Lutra lutra holt. European Journal of Wildlife Research 63(6). doi: 10.1007/s10344-017-1143-0
Frantz AC, Mc Devitt AD, Pope LC, Kochan $\mathrm{J}$, Davison J, Clements CF, Elmeros M, Molina-Vacas G, Ruiz-Gonzalez A, Balestrieri A, Van Den Berge K, Breyne P, San EDL, Agren EO, Suchentrunk F, Schley L, Kowalczyk R, Kostka BI, Cirovic D, Sprem N, Colyn M, Ghirardi M, Racheva V, Braun C, Oliveira R, Lanszki J, Stubbe A, Stubbe M, Stier N, Burke T (2014) Revisiting the phylogeography and demography of European badgers (Meles meles) based on broad sampling, multiple markers and simulations. Heredity 113(5): $443-453$

Henry C (1984) Eco-éthologie de l'alimentation du blaireau européen (Meles meles L.) dans une forêt du centre de la France. Mammalia 48(4): 489-503

Kowalczyk R, Jedrzejewska B, Zalewski A (2003) Annual and circadian activity patterns of badgers (Meles meles) in Bialowieza Primeval Forest (eastern Poland) compared with other Palaearctic populations. Journal of Biogeography 30(3): 463-472

Kruuk H, Parish T (1981) Feeding specialization of the European badger Meles meles in Scotland. Journal of Animal Ecology 50(3): 773-788

Lambert A (1990) L'exploitation des ressources alimentaires par le Blaireau eurasien (Meles meles L., 1758): de la description du régime à l'étude de la prédation. Dissertation, Université d'Orléans

Lebourgeois F (2020a) Le blaireau européen (Meles meles L.). Synthèse des connaissances européennes. Partie 1: choix de l'habitat, structure et densité spatiale des terriers. Revue Forestière Française 72(1): 11-32 
Lebourgeois F (2020b) Le blaireau européen (Meles meles L.). Synthèse des connaissances européennes. Partie 2 : groupes familiaux, dynamiques des populations et domaines vitaux. Revue Forestière Française 72(2): 99-118

Li F, Luo ZH, Li CL, Li CW, Jiang ZG (2013) Biogeographical patterns of the diet of Palearctic badger: Is badger an earthworm specialist predator? Chinese Science Bulletin 58(18): 2255-2261

Lindsay IM, Macdonald DW (1985) The effects of disturbance on the emergence of eurasian badgers in winter. Biological Conservation 34(4): 289-306

Markham A, Trigoni N, Macdonald DW, Ellwood SA (2012) Underground Localization in 3-D Using MagnetoInductive Tracking. Ieee Sensors Journal 12(6): 1809-1816

Martin LER, Byrne AW, O'Keeffe J, Miller MA, Olea-Popelka FJ (2017) Weather influences trapping success for tuberculosis management in European badgers (Meles meles). European Journal of Wildlife Research 63(30): 1-8

McClune DW, Kostka B, Delahay RJ, Montgomery WI, Marks NJ, Scantlebury DM (2015) Winter Is Coming: Seasonal Variation in Resting Metabolic Rate of the European Badger (Meles meles). Plos One 10(9). doi:

e013592010.1371/journal.pone.0135920

Neal E (1986) The natural history of Bagders. Book Club Associates. Guild Publishing, London

Noonan MJ, Markham A, Newman C, Trigoni $\mathrm{N}$, Buesching CD, Ellwood SA, Macdonald DW (2014) Climate and the Individual: Inter-Annual Variation in the Autumnal Activity of the European Badger (Meles meles). Plos One 9(1). doi: e8315610.1371/journal.pone.0083156

Noonan MJ, Markham A, Newman C, Trigoni $\mathrm{N}$, Buesching CD, Ellwood SA, Macdonald DW (2015) A new Magneto-Inductive tracking technique to uncover subterranean activity: what do animals do underground? Methods in Ecology and Evolution 6(5): 510-520

Nordström S (1975) Seasonall activity of lumbricids in southern Sweden. Oikos 26(3): 307-315

Page RJC, Ross J, Langton SD (1994) Seasonality of reproduction in the european badger Meles meles in south-west England. Journal of Zoology 233: 69-91

Paget RJ, Middleton ALV (1974) Some observations on the sexual activities of badgers in yorkshire in the months december-april. Journal of Zoology 173(2): 256-260

Roper TJ (1992) Badger Meles meles setts architecture, internal environment and function. Mammal Review 22(1): 43-53

Roper TJ, Moore JAH (2003) Ventilation of badger Meles meles setts. Mammalian Biology 68(5): 277-283

Roper TJ, Tait AI, Fee D, Christian SF (1991) Internal structure and contents of three badger (Meles meles) setts. Journal of Zoology 225: 115-124

Shepherdson DJ, Roper TJ, Lüps P (1990) Diet, food availability and foraging behaviour of badgers (Meles meles L.) in southern England. Zeitschrift Fur Saugetierkunde-International Journal of Mammalian Biology 55(2): 81-93

Tanaka H (2006) Winter hibernation and body temperature fluctuation in the 
Japanese badger, Meles meles anakuma.

Zoological Science 23(11): 991-997

Thornton PS (1988) Density and distribution of Badgers in south-west England-a predictive model. Mammal Review 18(1): $11-23$

Tsunoda M, Newman C, Buesching CD, Macdonald DW, Kaneko Y (2018) Badger setts provide thermal refugia, buffering changeable surface weather conditions. Journal of Thermal Biology 74: 226-233

Wandeler AI, Graf M (1982) The reproductive cycle of female badgers (Meles meles) in Switzerland. Revue Suisse De Zoologie 89(4): 1009-1016

Wong J, Stewart PD, Macdonald DW (1999) Vocal repertoire in the European badger (Meles meles): Structure, context, and function. Journal of Mammalogy 80(2): 570588 


\begin{tabular}{|l|c|c|c|c|}
\hline & \multicolumn{4}{|c|}{ Prequency of the different activities (in \%) } \\
\hline & Grooming & Bedding & Digging & Mating \\
\hline Dusk [18 to 24 h[ & 56 & 95 & 90 & 31 \\
\hline Night [0 to $4 \mathrm{~h}]$ & 15 & 4 & 8 & 22 \\
\hline Dawn ]4 to 9h] & 29 & 1 & 2 & 47 \\
\hline Number of days & 601 & 311 & 156 & 62 \\
\hline Percentage of the total & $39 \%$ & $20 \%$ & $10 \%$ & $4 \%$ \\
\hline Number of videos & 4660 & 1609 & 1970 & 468 \\
\hline Percentage of the total & $16 \%$ & $5 \%$ & $7 \%$ & $2 \%$ \\
\hline
\end{tabular}

Table 1 Frequency of the different activities (in \%) observed on the burrow from April 2013 to June 2018 per period. For each activity, the percentage of the total has been calculated from the total number of days $(\mathrm{n}=1538)$ and videos $(\mathrm{n}=29648)$. 


\begin{tabular}{|c|c|c|c|c|c|c|c|c|c|}
\hline & Month / Year & Grc & $\operatorname{ming}$ & & ding & & sing & & ing \\
\hline & & $\mathrm{N}$ & $\mathrm{D}$ & $\mathrm{N}$ & $\mathrm{D}$ & $\mathrm{N}$ & $\mathrm{D}$ & $\mathrm{N}$ & \\
\hline & January & 48 & 4 & 21 & 14 & 15 & 24 & 19 & - \\
\hline & February & 59 & 6 & 46 & 23 & 5 & 17 & 17 & - \\
\hline & March & 69 & 7 & 53 & 11 & 12 & 10 & 3 & - \\
\hline & April & 89 & 9 & 27 & 5 & 17 & 19 & 0 & - \\
\hline & May & 74 & 7 & 19 & 6 & 22 & 37 & 1 & - \\
\hline & June & 23 & 5 & 4 & 11 & 8 & 53 & 0 & - \\
\hline$\sum^{\circ}$ & July & 6 & 2 & 2 & 6 & 4 & 13 & 0 & - \\
\hline & August & 9 & 2 & 1 & - & 6 & 29 & 0 & - \\
\hline & September & 38 & 9 & 20 & 9 & 21 & 35 & 5 & - \\
\hline & October & 90 & 9 & 54 & 13 & 33 & 12 & 6 & - \\
\hline & November & 49 & 9 & 37 & 18 & 7 & 11 & 1 & - \\
\hline & December & 47 & 7 & 27 & 10 & 6 & 15 & 10 & - \\
\hline & 2013 & 48 & $22 \%$ & 43 & $20 \%$ & 3 & $1 \%$ & 2 & $1 \%$ \\
\hline & 2014 & 114 & $39 \%$ & 66 & $22 \%$ & 14 & $5 \%$ & 19 & $6 \%$ \\
\hline & 2015 & 162 & $56 \%$ & 91 & $31 \%$ & 54 & $19 \%$ & 13 & $4 \%$ \\
\hline$\underset{-10}{0}$ & 2016 & 105 & $36 \%$ & 47 & $16 \%$ & 49 & $17 \%$ & 20 & $7 \%$ \\
\hline & 2017 & 118 & $40 \%$ & 43 & $14 \%$ & 26 & $9 \%$ & 3 & $1 \%$ \\
\hline & 2018 & 54 & $36 \%$ & 21 & $14 \%$ & 10 & $7 \%$ & 5 & $3 \%$ \\
\hline
\end{tabular}

Table 2 Total number ( $\mathrm{N}$ in days) and mean duration ( $\mathrm{D}$ in minutes) of the different activities observed on the burrow from April 2013 to June 2018 presented by month and by year ( $\mathrm{n}=1538$ days). For the year, the percentage corresponds to the ratio between the number of days of each activity and the total number of monitored days (216, 294, 290, 292, 298 and 148 from 2013 to 2018). The monthly mean duration for mating is not given as the duration was only quantified for 32 cases. 


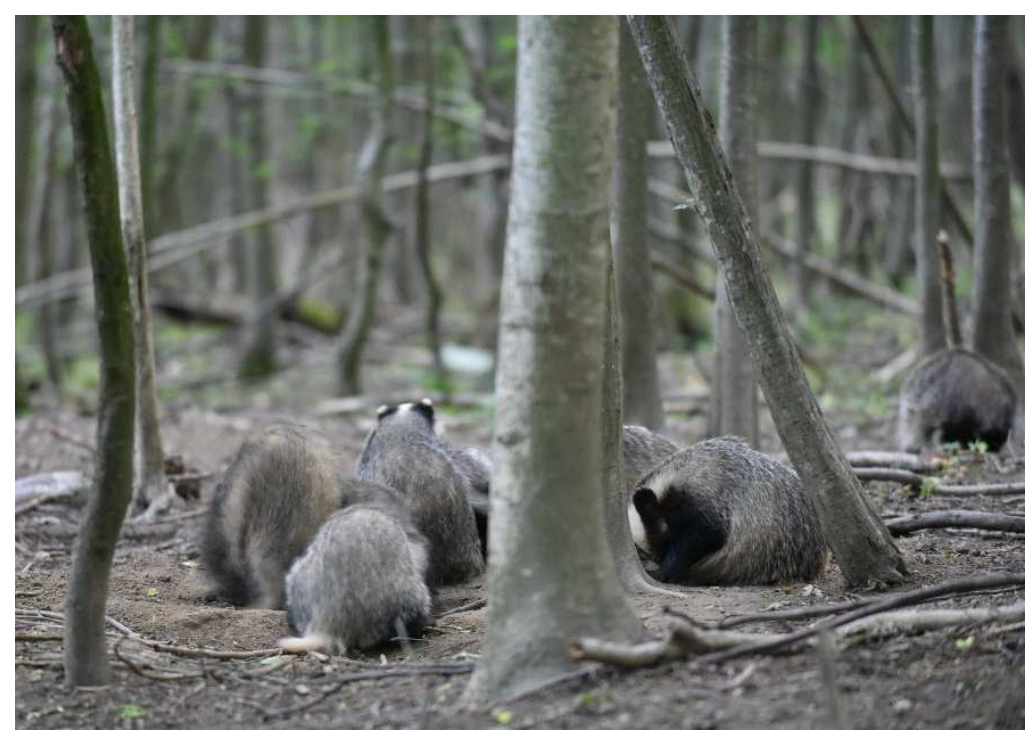

Fig. 1 Collective grooming (seven badgers) in May just after the emergence of the burrow.

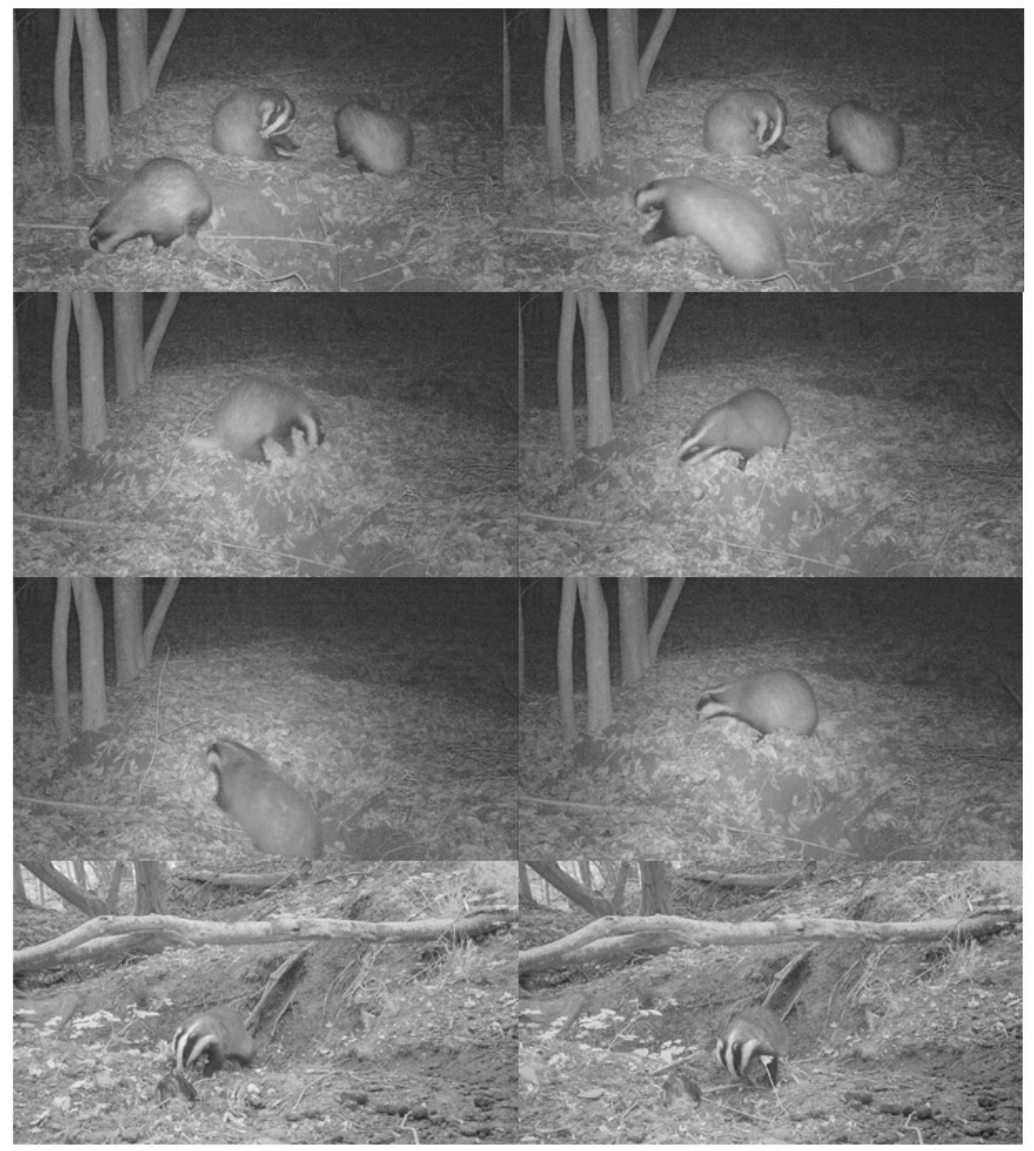

Fig. 2 Bedding collecting in early November. The bedding dragged into the burrow was made up exclusively of bundles of hornbeam leaves collected in the surrounding area of the burrow (screen capture from videoclips). 


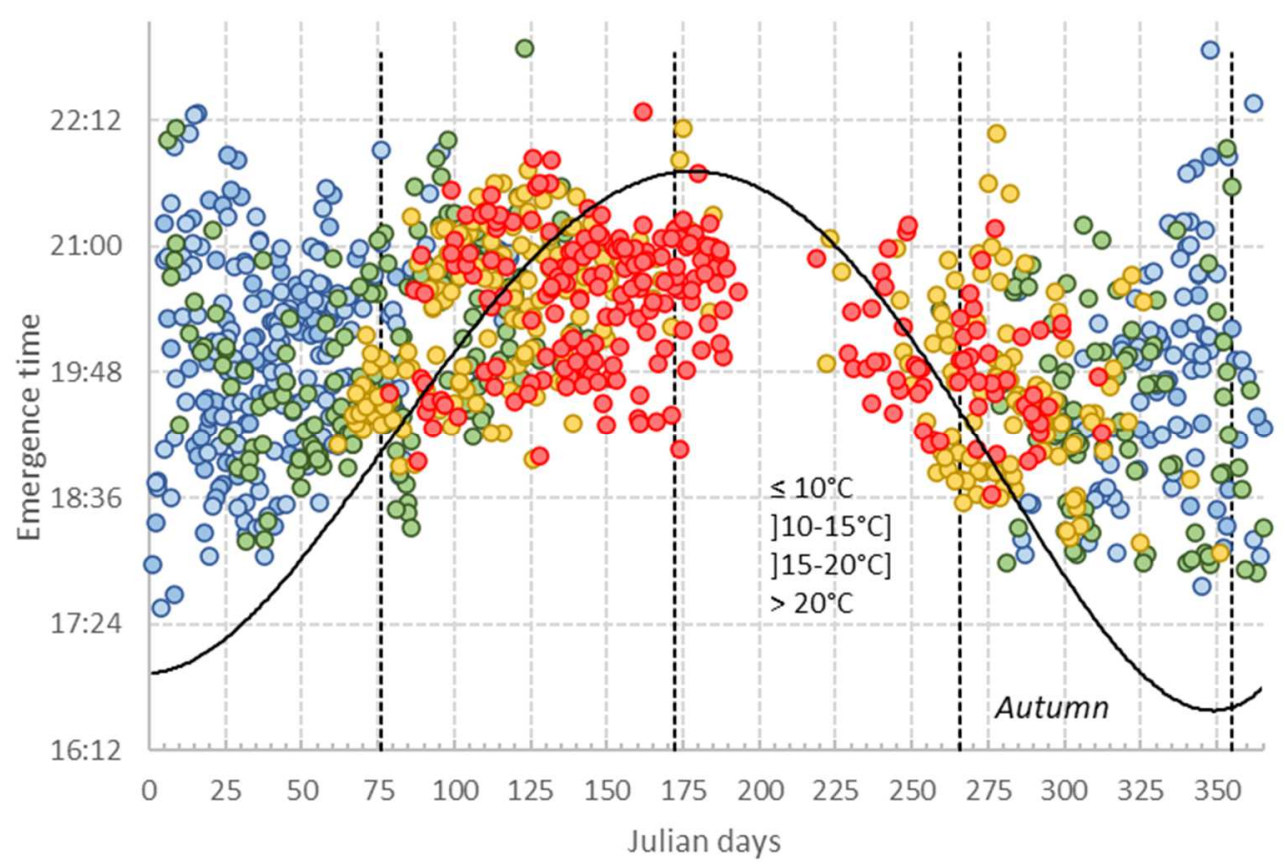

Fig. 3 Seasonal variations of emergence time relatively to sunset curve and daily maximum temperature (in ${ }^{\circ} \mathrm{C}$ ) (emergence time and sunset curve are expressed in local time; $48.69 \mathrm{~N}-$ 06.27E). N=1092 observations (period April 2013 to June 2018). No camera trapping between mid-July to mid-August (Julian days: 200 to 225, excepted in 2017).

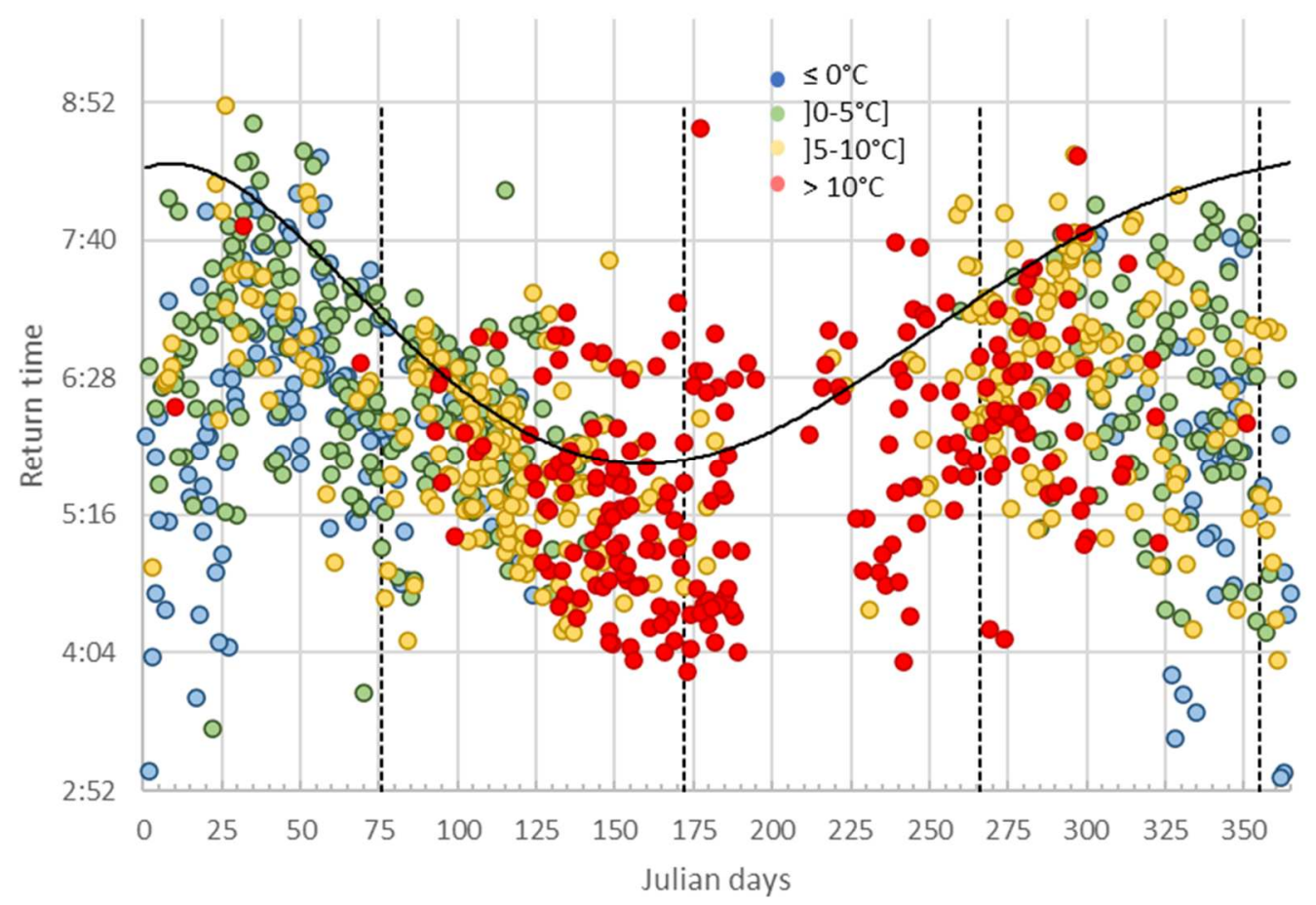

Fig. 4 Seasonal variations of return time relatively to sunrise curve and nightly minimum temperature $\left({ }^{\circ} \mathrm{C}\right)$ (return time and sunrise curve are expressed in local time; $48.69 \mathrm{~N}-06.27 \mathrm{E}$ ). $\mathrm{N}=1026$ observations (period April 2013 to June 2018). No camera trapping between mid-July to mid-August (Julian days: 200 to 225, excepted in 2017). 